\title{
EFEKTIVITAS EKSTRAK BUNGA KAMBOJA PUTIH (Plumeria alba. L) SEBAGAI DENTURE CLEANSER TERHADAP PER- TUMBUHAN Candida albicans PADA BAHAN BASIS GIGI TIRUAN NILON TERMOPLASTIK (Valplast) Effectiveness Of Cambodia White Flower Extract (Plumeria alba L.) As Denture Cleanser On The Growth Of Candida albicans In Base Material Of Artificial Teeth Nylon Thermoplastic (Valplast)
}

\author{
Fitriana Wadianur, Lusi Hidayati, Yani Corvianindya \\ ${ }^{1}$ Fakultas Kedokteran Gigi Universitas Jember \\ Jl. Kalimantan 37 Jember 68121 \\ e-mail : fitrianawadianur12@gmail.com
}

\begin{abstract}
Background: Nylon thermoplastic (Valplast) is a flexible denture base that is used in the denture. The problem that often occurs in the use of denture namely the denture stomatitis are commonly caused by C. albicans. Denture cleanser is needed to prevent denture stomatitis by lowering the amount of C. albicans. Recently, denture cleanser from natural materials is being develope, one of them is cambodia white flower (Plumeria alba L.) extract. Cambodia white flower (Plumeria alba L.) contains bioactive compounds that are antibacterial and antifungal. Objective: To determine the effectiveness of immersion extract of cambodia white flower (Plumeria alba L.) with various concentrations as denture cleanser to amount of $C$. albicans in nylon thermoplastic (Valplast). Material and Methods: 25 plates nylon thermoplastic $(10 \times 10 \times 1 \mathrm{~mm})$ were prepared and divided into 5 groups. The plates then contaminated with $C$. albicans, after that it was soaked in cambodia white flower extracts with varying concentrations for 30 minutes. The plates are subsequently placed in SDB media. Method to test the effectiveness of extract was done by looking at the SDB media turbidity with a spectrophotometer. Results and Conclusion: Cambodia white flower extract was effective in lowering the amount of $C$. albicans in denture base thermoplastic nylon. Cambodia white flower contained tannin, flavonoid, alkaloid and saponin which acted as antifungal that could decrease the amount of C. albicans.
\end{abstract}

Keywords: Antifungal, Candida albicans, Nylon Thermoplastic and Cambodia White Flower 


\begin{abstract}
Abstrak
Latar Belakang: Nilon termoplastik (valplast) adalah basis gigi tiruan fleksibel yang digunakan pada gigi tiruan. Masalah yang sering terjadi dalam pemakaian gigi tiruan yaitu terjadinya denture stomatitis yang umumnya disebabkan oleh $C$. albicans Penggunaan denture cleanser diperlukan untuk mencegah terjadinya denture stomatitis dengan menurunkan jumlah $C$. albicans. Saat ini mulai dikembangkan denture cleanser dari bahan alam, salah satunya yaitu ekstrakbunga kamboja putih (Plumeria alba L.). Bunga kamboja putih (Plumeria alba L.) mengandung senyawa bioaktif yang bersifat antibakteri dan antijamur. Tujuan Penelitian: Mengetahui efektifitas perendaman ekstrak bunga kamboja putih (Plumeria alba L.) dengan berbagai konsentrasi sebagai denture cleanser tiruan terhadap pertumbuhan $C$. albicans pada nilon termoplastik (valplast). Materi dan Metode: 25 lempeng nilon termoplastik $(10 \times 10 \times 1 \mathrm{~mm})$ disiapkan dan dibagi menjadi 5 kelompok. Lempeng kemudian dikontaminasi $C$. albicans, setelah itu direndam dalam ekstrak bunga kamboja putih dengan berbagai konsentrasi selama 30 menit. Lempeng selanjutnya diletakkan dalam media SDB. Metode pengujian efektivitas ekstrak dilakukan dengan melihat kekeruhan media SDB dengan spektrofotometer. Hasil dan Simpulan: Ekstrak bunga kamboja putih efektif dalam menurunkan jumlah $C$. albicans pada basis gigi tiruan nilon termoplastik. Bunga kamboja putih menganung senyawa antijamur yaitu tanin, flavonoid, alkaloid dan saponin sehingga menurunkan jumlah C. Albicans.
\end{abstract}

Kata kunci: Antijamur, Bunga Kamboja Putih, Candida albicans dan Nilon Termoplastik

\section{Pendahuluan}

Kehilangan gigi merupakan suatu keadaaan tanggalnya gigi individu dari soketnya yang disebabkan oleh pencabutan karena karies atau penyakit periodontal, trauma, dan penyakit sistemik. Jika gigi yang hilang tidak segera diganti dapat menimbulkan kesulitan bagi pasien sendiri, seperti mengunyah makanan, adanya gigi yang supra erupsi, miring atau bergeser. Penggantian gigi yang hilang dapat dilakukan dengan pembuatan gigi tiruan lepasan atau gigi tiruan cekat [1].

Nilon termoplastik adalah salah satu basis gigi tiruan yang bersifat fleksibel dan sudah banyak digunakan oleh pasien yang menggunakan gigi tiruan. Nilon termoplastik bersifat biokompatibel, stabil dan tahan terhadap pemuaian serta beban yang tinggi. Selain itu, niIon termoplastik bebas monomer sehingga merupakan pilihan bagi pasien yang alergi terhadap bahan yang menyisakan monomer dalam polimerisasinya [2].

Penggunaan bahan basis gigi tiruan tersebut memiliki kekurangan yaitu kerentanan warna basis bahan untuk berubah, mengalami stain, penyerapan air yang tinggi dan pembentukan permukaan yang kasar setelah jangka waktu yang pendek. Permukaan bahan basis yang kasar tersebut dapat dapat menjadi tempat penumpukan plak gigi tiruan [3].

Menurut beberapa studi yang dilakukan di universitas dan rumah sakit, $65 \%$ dari pe- makaian denture memiliki masalah yang disebabkan oleh C. albicans (yang merupakan spesies Candida paling banyak dijumpai) [4]. C. albicans dapat melakukan penetrasi pada nilon termoplastik dan tumbuh pada permukaan gigi tiruan sehingga dapat menginfeksi jaringan lunak dan merupakan penyebab terjadinya denture stomatitis [2].

Pencegahan denture stomatitis dapat dilakukan secara rutin dengan membersihkan gigi tiruan baik secara mekanik maupun secara kimia. Saat ini sudah mulai dikembangkan tanaman herbal dan salah satu bahan alam yang dapat digunakan adalah ekstrak bunga kamboja putih (Plumeria alba L.). Bunga kamboja putih (Plumeria alba L.) diketahui mengandung zat-zat bioaktif misalnya alkaloid, flavonoid, fenol, tannin, trepenoid, glikosida, flobatanin. Dengan kandungan yang dimilikinya tersebut, bunga kamboja putih memiliki fungsi sebagai antibakteri dan antijamur [5].

Berdasarkan uraian di atas, peneliti ingin mengetahui efektifitas dari ekstrak bunga kamboja putih (Plumeria alba L.) sebagai denture cleanser dalam menghambat pertumbuhan C. albicans pada nilon termoplastik (valplast).

\section{Metode Penelitian}

Jenis penelitian yang digunakan adalah eksperimental laboratoris dengan rancangan penelitian post test only control group design. Penelitian ini dilakukan di bagian Mikrobiologi 
Univeristas Jember, Laboratorium Bioscience, dan Laboratorium Teknik Kedokteran Gigi. Pelaksanaan penelitian dilakukan pada bulan November sampai Desember 2016.

Bahan yang digunakan adalah ekstrak bunga kamboja putih dengan konsentrasi $25 \%$, $50 \%, 75 \%$ dan $100 \%$. Sebanyak $0,5 \mathrm{~kg}$ bunga kamboja putih dicuci dan dikeringkan menggunakan oven dengan suhu $45^{\circ} \mathrm{C}$. Setelah kering, bunga kamboja diblender kemudian diayak untuk mendapatkan bentukan serbuk halus. Didapatkan 71,4gram bunga kamboja putih dalam bentuk serbuk. Selanjutnya serbuk bunga kamboja putih dimaserasi dengan menggunakan etanol $70 \%$ sebagai pelarut dengan perbandingan 7 kali dari berat serbuk untuk mendapatkan sediaan ekstrak (Morgan, 2009: 2$3)$.

Pengenceran dilakukan dengan menggunakan aquades steril untuk mendapatkan konsentrasi 25\%, 50\%, 75\%.Pengenceran dilakukan di dalam laminar flow menggunakan mikropipet yang diberi tip.Ekstrak dengan konsentrasi $25 \%$ diperoleh dari $1 \mathrm{ml}$ ekstrak bunga kamboja putih ditambah dengan $3 \mathrm{ml}$ aquades steril. Ekstrak bunga kamboja putih dengan konsentrasi $50 \%$ diperoleh dari $2 \mathrm{ml}$ ekstrak ditambah dengan $2 \mathrm{ml}$ aquades steril. Dan ekstrak bunga kamboja putih dengan konsentrasi $75 \%$ diperoleh dari $3 \mathrm{ml}$ ekstrak ditambah dengan 1 $\mathrm{ml}$ aquades steril.Setelah diencerkan, ekstrak dengan berbagai konsentrasi tersebut dimohomogenkan dengan menggunakan thermolyne.

Sampel yang digunakan yaitu lempeng nilon termoplastik (valplast) berbentuk persegi

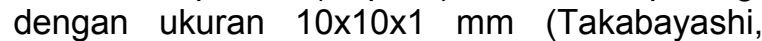
2010). Jumlah sampel yang digunakan sebanyak 25 sampel. Sampel dibagi menjadi 5 kelompok, 1 kelompok kontrol dan 4 kelompok perlakuan. Sebelum hari perlakuan, semua alat dan sampel yang akan digunakan disterilkan menggunakan autoklaf selama 15 menit dengan suhu $121^{\circ} \mathrm{C}$. Setelah disterilkan, sampel dikontaminasi dengan $C$. albicans dengan cara memasukkan masing-masing lempeng ke dalam petridish yang berisi suspensi $C$. albicans dan diinkubasi selama 24 jam pada suhu $37^{\circ} \mathrm{C}$.

Selanjutnya sampel direndam dalam 4 $\mathrm{ml}$ aquades steril dan ekstrak bunga kamboja putih dengan berbagai konsentrasi.Pada kelompok I (kelompok control), 5 buah sampel direndam dalam $4 \mathrm{ml}$ aquades steril selama 30 menit. Untuk kelompok II, 5 buah lempeng nilon termoplastik direndam dalam $4 \mathrm{ml}$ ekstrak bunga kam- boja putih dengan konsentrasi $25 \%$ selama 30 menit. Pada kelompok III, IV dan V, 5 lempeng direndam dalam ekstrak bunga kamboja putih dengan konsentrasi berurutan yaitu 50\%, 75\% dan $100 \%$.

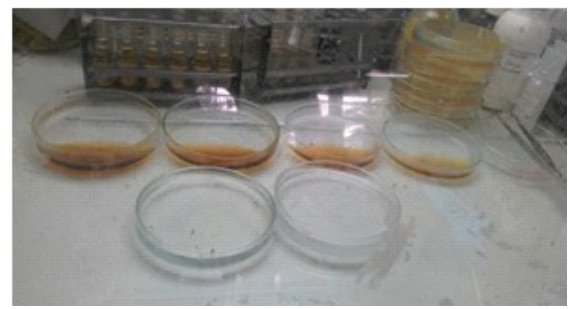

Gambar 1. Lempeng nilon termoplastik yang direndam dalam aquades steril dan ekstrak bunga kamboja putih

Setelah perendaman, sampel dicuci dengan PBS $2 x$ selama 15 detik untuk menghilangkan sisa perendaman. Kemudian sampel dimasukkan dalam tabung yang berisi $2 \mathrm{ml}$ SDB dan dilakukan vibrasi dengan menggunakan thermolyne selama 30 detik untuk melepaskan C. albicans yang melekat pada lempeng nilon termoplastik. Selanjutnya, dilakukan penghitungan $C$. albicans dengan menggunakan spektrofotometer.

\section{Hasil Penelitian}

Hasil penelitian tentang uji efektivitas ekstrak bunga kamboja putih terhadap jumlah C. albicans pada basis gigi tiruan nilon termoplastik dapat dilihat melalui perhitungan konsentrasi $C$. albicans. Pada tabel 1, hasil perhitungan nilai konsentrasi $C$. albicans pada kelompok sampel penelitian menunjukkan bahwa terdapat perbedaan yang signifikan antara tiap kelompok sampel. Data hasil penelitian yang telah diperoleh kemudian dianalisa menggunakan uji normalitas dan uji homogenitas untuk mengetahui bahwa data terdistribusi normal dan homogen sebagai syarat dalam melakukan uji statistik parametrik.

Uji normalitas dilakukan untuk mengetahui apakah distribusi data hasil penelitian pada masing-masing kelompok mengikuti kurva distribusi normal atau tidak. Uji normalitas dilakukan dengan menggunakan Kolmogorov-Smirnov Test dengan nilai $p>0,05$. Hasil uji normalitas menunjukkan bahwa hasil penelitian memiliki nilai signifikansi atau probabilitas $(p)$ lebih besar dari $0,05(p>0,05)$. Nilai probabilitas yang diperoleh masing-masing kelompok berturut-turut dari kelompok I sampai $\mathrm{V}$ yaitu 0,$374 ; 0,253 ; 0,181 ; 0,252 ;$ dan 
0,321. Hal ini menunjukkan bahwa data dari masing-masing kelompok berdistribusi normal.

Tabel 1 Hasil perhitungan konsentrasi $C$. albicans setelah dikonversikan pada rumus dalam $\mathrm{n} \times 10^{8}$ (CFU/ml)

\begin{tabular}{cccccc}
\hline Sampel & I & II & III & IV & V \\
\hline $\mathbf{1}$ & 6,399 & 4,800 & 3,900 & 3,399 & 3,201 \\
$\mathbf{2}$ & 6,201 & 4,700 & 3,999 & 3,501 & 2,901 \\
$\mathbf{3}$ & 6,399 & 5,001 & 3,801 & 3,300 & 3,000 \\
$\mathbf{4}$ & 6,399 & 4,599 & 4,200 & 3,399 & 3,201 \\
$\mathbf{5}$ & 6,801 & 4,700 & 4,299 & 3,099 & 3,099 \\
\hline Rata-rata & $\mathbf{6 , 4 3 9}$ & $\mathbf{4 , 7 6 0}$ & $\mathbf{4 , 0 4 0}$ & $\mathbf{3 , 3 4 0}$ & $\mathbf{3 , 0 8 0}$ \\
\hline & & & &
\end{tabular}

Keterangan:

Kelompok I = Lempeng nilon termoplastik direndam dalam aquades

Kelompok II = Lempeng nilon termoplastik direndam dalam ekstrak $P$. alba konsentrasi $25 \%$

Kelompok III = Lempeng nilon termoplastik direndam dalam ekstrak $P$. alba konsentrasi $50 \%$

Kelompok IV = Lempeng nilon termoplastik direndam dalam ekstrak $P$. alba konsentrasi $75 \%$

Kelompok $\mathrm{V}=$ Lempeng nilon termoplastik direndam dalam ekstrak $P$. alba konsentrasi $100 \%$

Uji homogenitas digunakan untuk mengetahui keseragaman sampel. Uji homogenitas menggunakan Levene Test dengan nilai $p>0,05$. Hasil uji homogenitas menunjukkan bahwa data hasil penelitian memiliki nilai signifikansi atau probabilitas $(p)$ lebih besar dari 0,05, yakni 0,433. Ini menunjukkan bahwa data yang diperoleh dari penelitian ini adalahhomogen. Oleh karena data penelitian yang diperoleh berdistribusi normal dan homogeny, maka analisa data dilanjutkan dengan uji statistik parametric menggunakan One Way ANOVA dengan tingkat kepercayaan antar kelompok perlakuan sebesar 95\% $(\alpha=0,05)$. Uji statistik parametrik One Way ANOVA dilakukan untuk melihat adanya perbedaan antar kelompok perlakuan dengan nilai $p<0,05$. Hasil uji One Way ANOVA memperlihatkan bahwa terdapat perbedaan signifikan antar kelompok perlakuan dengan nilai signifikansi $0,000(p<0,05)$. Sehingga dapat disimpulkan bahwa terdapat perbedaan yang signifikan antar kelompok perlakuan.

Setelah dilakukan uji beda, selanjutnya dilakukan uji LSD (Least Significant Difference) untuk mengetahui lebih lanjut perbedaan pada setiap kelompok sampel. Hasil uji LSD memperlihatkan bahwa terdapat perbedaan yang signifikan pada masing-masing kelompok perlakuan dengan nilai signifikansi 0,000 $(p>0,05)$. Hasil rigkasan uji LSD dapat dilihat pada Tabel 2.

Tabel 2 Ringkasan hasil uji LSD

\begin{tabular}{c|c|c|c|c|c}
\hline Kelompok & I & II & III & IV & V \\
\hline I & - & 0.000 & 0.000 & 0.000 & 0.000 \\
II & 0.000 & - & 0.000 & 0.000 & 0.000 \\
III & 0.000 & 0.000 & - & 0.000 & 0.000 \\
IV & 0.000 & 0.000 & 0.000 & - & 0.007 \\
V & 0.000 & 0.000 & 0.000 & 0.007 & - \\
\hline
\end{tabular}

\section{Pembahasan}

Penelitian ini menggunakan lempeng yang terbuat dari bahan nilon termoplastik. Nilon termoplastik merupakan bahan yang digunakan sebagai basis gigi tiruan. Lempeng nilon termoplastik ini kemudian direndam dalam aquades dan ekstrak bunga kamboja putih sesuai dengan pembagian kelompok perlakuan.

Nilai absorbansi $C$. albicans pada lempeng nilon termoplastik yang semakin rendah dikarenakan ekstrak bunga kamboja putih memiliki senyawa-senyawa aktif yang dapat menghambat perlekatan $C$. albicans pada lempeng nilon termoplastik dikarenakan ekstrak bunga kamboja putih memiliki senyawasenyawa aktif yang dapat menghambat perlekatan C. albicans pada lempeng nilon termoplastik seperti tanin, flavonoid, saponin dan alkaloid. Sehingga semakin tinggi konsentrasi ekstrak bunga kamboja putih, maka semakin banyak pula kandungan senyawa aktif yang terdapat di dalamnya.

Ekstrak bunga kamboja putih efektif terhadap penurunan jumlah $C$. albicans karena memiliki empat senyawa kimia yang bersifat antijamur yaitu tanin, flavonoid, saponin dan alkaloid. Hal ini didukung oleh penelitian yang dilakukan oleh Sibi (2012) yang membuktikan bahwa ekstrak bunga kamboja putih (P.alba) mengandung keempat senyawa antijamur tersebut.

Tanin merupakan senyawa metabolik sekunder pada tumbuhan dan merupakan salah satu grup fenol. Tanin memiliki sifat antimikroba karena memiliki senyawa astringen. Senyawa astingen dari tanin diduga dapat mengganggu aktivitas dinding sel dan membran sel $C$. albicans [6]. Mekanisme tersebut terjadi diduga dengan cara saat tain melekat pada dinding sel C. albicans, selanjutnya dinding sel mengalami perubahan morfologi menjadi lebih tebal sehingga terjadi perubahan pada ruang antara dinding sel dan membran plasma yang bisa dis- 
ebut sebagai gangguan permeabilitas. Gangguan permeabilitas dapat menyebabkan aktivitas sel terganggu sehingga sel menjadi rapuh dan akhirnya mati [7].

Senyawa flavonoid merusak sel jamur dengan melakukan penetrasi ke dalam membran sel sehingga menyebabkan terkoagulasinya protein (enzim) pada membran sel yang mengakibatkan struktur protein menjadi rusak. Ketidakstabilan pada dinding sel dan membran sel jamur menyebabkan fungsi permeabilitas selektif, fungsi pengangkutan aktif dan pengendalian susunan protein dari sel jamur menjadi terganggu, yang akan berakibat sel menjadi kehilangan bentuk dan terjadi lisis [8]. Sementara itu, senyawa saponin dapat bekerja sebagai antijamur dengan cara menurunkan tegangan permukaan pada dinding sel jamur sehingga mengganggu permeabilitas sel [9].

Senyawa kimia keempat yang mengandung antimikroba dan antijamur dalam ekstrak bunga kamboja putih ialah alkaloid. Alkaloid merupakan senyawa organik yang terdapat di alam dan bersifat basa atau alkali. Olivia et al. (2004) menyatakan bahwa alkaloid adalah zat aktif dari tanaman yang berfungsi sebagai obat dan activator kuat bagi sel imun yang menghancurkan bakteri, virus, jamur dan sel kanker [10]. Mekanisme alkaloid yang diduga adalah dengan cara mengganggu komponen rantai DNA pada inti sel. DNA sel pada mikroba rusak karena alkaloid memiliki gugus basa. Apabila gugus basa tersebut mengalami kontak dengan mikroba, maka gugus basa itu akan bereaksi dengan senyawa asam-asam amino yang menyusun dinding sel dan DNA penyusun inti sel. Reaksi ini menyebabkan terjadinya perubahan susunan rantai DNA, sehingga terjadi kerusakan DNA dan pada akhirnya menyebabkan lisis. Hal ini membuat lapisan dinding sel tidak terbentuk secara utuh sehingga menyebabkan kematian pada sel tersebut [11].

Efektivitas tanin, flavonoid, saponin dan alkaloid dalam menghambat pertumbuhan $C$. albicans didukung oleh penelitian Arundhina et al. (2014) yang mengggunakan ekstrak daun alamanda untuk menghambat pertumbuhan $C$. albicans dan Pityrosporum ovale. Dalam penelitiannya, Arundhina menjelaskan bahwa daun alamanda mengandung senyawa kimia tertentu yang bersifat antijamur yaitu tanin, flavonoid, saponin dan alkaloid, sama seperti bunga kamboja putih yag juga mengandung keempat senyawa tersebut [12].

Keempat senyawa ini terkandung dalam suatu larutan yang juga dapat memasuki celah mikroporositas pada permukaan bahan basis gigi tiruan nilon termoplastik. Hal ini juga didukung oleh pendapat Anusavice (2004) yang menyatakan bahwa penyerapan cairan pada niIon termoplastik terjadi melalui proses difusi. Difusi merupakan kemampuan suatu cairan untuk memasuki rongga yang tersedia dengan menggunakan energy pasif [13].

Perlekatan C. albicans pada basis gigi tiruan nilon termoplastik dipengaruhi oleh beberapa faktor seperti kekasaran permukaan, sifat kimia, sifat fisik dan sifat hidrofobik dari nilon termoplastik itu sendiri [4]. Kekasaran permukaan nilon termoplastik bisa didapatkan karena sifatnya yang sukar dipulas [14]. Selain itu, perlekatan C. albicans pada nilon termoplastik dipengaruhi sifat nilon termoplastik yang mudah menyerap air. Nilon termoplastik mudah menyerap air dikarenakan kepemilikan gugus hidroksil $(-\mathrm{COOH})$ yang bersifat polar, sehingga karakteristiknya hidrofilik. Air biasanya diserap lebih cepat dari pada komponen yang larut, sehingga terdapat penambahan massa. Penyerapan air pada basis gigi tiruan nilon termoplastik terjadi secara difusi. Tinggi rendahnya koefisien difusi dapat mempengaruhi penyerapan air yang terjadi. Koefisien difusi dipengaruhi oleh suhu penyimpanan (suhu oral dan suhu ruangan) dan ketebalan dari basis. Akibat dari penyerapan air yang terjadi selain terjadinya pertambahan massa, juga dapat berpengaruh pada stabilitas dimensi basis protesa, terjadinya ekspansi linier, molekul air masuk dapat mengganggu ikatan polimer sehingga dapat merubah karakteristik fisik dari polimer tersebut, salah satunya ialah kekasaran permukaan [15].

Mekanisme perlekatan C. albicans pada nilon termoplastik juga dapat disebabkan tegangan permukaan bahan. Sudut kontak cairan pada permukaan yang cukup halus berbanding terbalik dengan tingkat pembasahan permukaan, sehingga semakin tinggi sudut kontak cairan pada permukaan menyebabkan semakin kecilnya tegangan permukaan yang terjadi [16]. Tegangan permukaan dapat memengaruhi pembasahan permukaan basis gigi tiruan oleh saliva terhadap daya adhesi mikroorganisme pada permukaan [4].

\section{Simpulan dan Saran}

Konsentrasi ekstrak bunga kamboja putih yang semakin tinggi, menyebabkan nilai absorbansi C. albicans semakin rendah. Kesimpulan dari penelitian ini yaitu ekstrak bunga kamboja putih efektif dalam menurunkan 
jumlah C. albicans pada basis gigi tiruan nilon termoplastik.

Adapun saran dalam penelitian ini yaitu perlu dilakukan penelitian lebih lanjut mengenai biokompabilitas ekstrak bunga kamboja putih terhadap jaringan rongga mulut, perlu dilakukan penelitian lebih lanjut mengenai efektivitas ekstrak bunga kamboja putih menggunakan metode rebusan dan infusa serta perlu dilakukan penelitian lebih lanjut mengenai dosis paling efektif dari ekstrak bunga kamboja putih.

\section{Daftar Pustaka}

[1] McMillan, Anne S. Emotional Effects Of Tooth Loss. Int J. Prosthodontics. 2004; 17(2): 172-6.

[2] Nuning F, Oktanauli P, Tiagitha W. Gigi Tiruan Sebagian Lepasan Fleksibel Sebagai Alternative Perawatan Kehilangan Gigi. JITEKGI. 2011; 7: 11-4.

[3] Wurangian, I. Aplikasi dan Desain Nilon Termoplastik (Valplast) pada Gigi Tiruan Sebagian Lepasan. Jurnal IImiah dan Teknologi Kedokteran Gigi. 2010; 2:63-68.

[4] Ahmad ZM, Mustafa EA, Jawad IA. Adherence of Candida albicans to Flexible Denture Base Material.Al-Rafidain Dent J. 2012; 12(2): 229-235.

[5] Syakira, M.H. \& Brenda L. Antibacterial Capacity of Plumeria alba Petals. World Academy of Science, Engineering and Technology. 2010; 44:1473-1476.

[6] Vasconcelos, L.C.S., Sampaio, F.C., Sampaio, M. C. C., Pereira, M. S. V., Higino, J.S., \& Peixoto, M. H. P. 2006. Minimum Inhibitory Concentration of Adherence of Punica granatum Linn (pomegranate) Gel Against S.mutans, S. milis and C. albicans. Braz. Dent. J. 17(3): 223-227.

[7] Miguel, M. G., Neves, M. A., \& Antunes, M. D. Pomegranate (Punicagranatum L.): $A$ Medicinal Plant With Myriad Biological
Properties-A short review. J. Med. Plant Res. 2010; 4(25): 2836-2847.

[8] Soeka, Y. S., Naiola, E., danSulistyo, J. Aktivitas Antimikroba Flavonoid-Glikosida Hasil Sintesis Secara Transglikosilasi Enzimatik. Berita Biologi. 2007; 8(6): 455464.

[9] Robinson, T. Kandungan Organik Tumbuhan Tinggi. Bandung: ITB; 1995.

[10] Olivia F., Alam S., dan Hadibroto I. Seluk Beluk Food Suplement. Jakarta: PT Gramedia; 2004.

[11]Aniszewki T. Alkaloid-Secrets of Life. Amsterdam: Elsevier; 2007.

[12] Arundhina, E., Soegihardjo, C. J., Sidharta, B. B. R. 2014. Aktivitas Ekstrak Etanol Daun Alamanda (Allamanda cathartica L.) Sebagai Anijamur Terhadap Candida albicans dan Pytirosporum ovale secara In Vitro. Skripsi. Yogyakarta: Fakultas Teknobiologi Universitas Atmajaya.

[13]Anusavice, K.J. 1996. Philips Science Dental Material $\left(10^{\text {th }}\right.$ ed.) Terjemahan oleh Budiman, J.A.,Purwoko, S. 2004. Philip:Buku Ajar IImu Bahan Kedokteran Gigi (10 th ed.). Jakarta: EGC.

[14]Durkan, Rukiye, Elif Aydogan AYAZ, Bora Bagis, Ayhan Gurbuz, Nilgun Ozturk and Fatih Mehmet Korkmaz. Comparative Effects of Denture Cleansers on Physical Properties of Polyamide and Polymethyl Methacrylate Base Polymers. Dental Materials Journal 2013; 12(3): 367-375.

[15] Fadhilah, Alfi, Widyapramana Dwi Atmaja. The Influence Of Temperature And Longing Of Soak Towards Absorbing Water In The Basic Of Denture Thermoplastic Nylon. IDJ 2013; 2(1): 80-86.

[16] Combe, E.C., 1989. Notes On Dental Material. Terjemahan oleh Slamet Taringan, 1992. Sari Dental Material. Jakarta: Balai Pustaka. 